International Journal of Current Advanced Research

ISSN: O: 2319-6475, ISSN: P: 2319 - 6505, Impact Factor: SJIF: 5.995

Available Online at www.journalijcar.org

Volume 6; Issue 4; April 2017; Page No. 3094-3097

DOI: http://dx.doi.org/10.24327/ijcar.2017.3097.0191

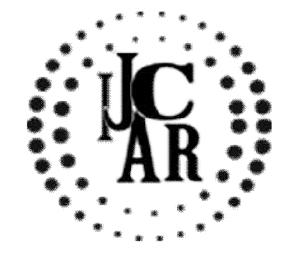

Research Article

\title{
KNOWLEDGE AND AWARENESS AMONG DENTAL PRACTITIONER REGARDING THE MANAGEMENT OF ANTERIOR OPEN BITE
}

\section{S.JiteshBDS ${ }^{1}$ and Ashish.R.Jain MDS, MD.ACU.VARMA ${ }^{2}$}

${ }^{1}$ Department of Prosthodontics, Saveetha Dental College and Hospital, Chennai, India

${ }^{2}$ Department of Prosthodontics, Saveetha Dental College and Hospitals, Saveetha University, Chennai, India

\begin{tabular}{l}
\hline A R T I C L E I N F O \\
\hline Article History: \\
Received $11^{\text {th }}$ January, 2017 \\
Received in revised form $19^{\text {th }}$ February, 2017 \\
Accepted $22^{\text {nd }}$ March, 2017 \\
Published online $28^{\text {th }}$ April, 2017
\end{tabular}

Key words:

Anterior Open Bite, Dental practitioers,

Awareness, Management

\begin{abstract}
A B S T R A C T
Background: Anterior open bites can be the result of a digit, or tongue-thrust habit, leading to the undereruption of the maxillary and mandibular incisor teeth. Treatment of the former requires correction of the habit, followed by the extrusion of the undererupted incisors, but with the popularity of miniscrew implants, it is only natural to look as these devices as an alternate treatment option for the correction of anterior open bites

Aim: To study about the knowledge and awareness among Dental practitioners regarding the management of anterior open bite

Materials and Methods: The questionnaire includes closed ended questions regarding the knowledge and attitude of the participants towards the management of anterior open bite. The survey was done on 100 participants and the participants included clinicians and postgraduates students. Data collection and analysis was done.

Result: About $97 \%$ of the dental practitioner were aware about the anterior open bite,and only about $87 \%$ of subjects have adequate knowledge about management of anterior open bite

Conclusion: This study shows that even though the dental practitioner were aware of anterior open bite they should also have adequate knowledge about the management of anteior open bites. Therefore increase in awareness among dental practitioner about the management of anterior open bite is still required.
\end{abstract}

Copyright $₫ 2017$ S.JiteshBDS et al. This is an open access article distributed under the Creative Commons Attribution License, which permits unrestricted use, distribution, and reproduction in any medium, provided the original work is properly cited.

\section{INTRODUCTION}

The term "open bite" was coined by Caravelli in 1842 as a distinct classification of malocclusion and can be defined in different manners ${ }^{1}$ Some authors have determined that open bite, ora tendency toward open bite, occurs when overbite is smaller than what is considered normal.Others argue that open bite is characterized by end-on incisal relationships. Finally, others requirethat no incisal contact be present before diagnosing open bite. For semantic reasons, andbecause it is in agreement with most definitions in the literature ${ }^{2,3,4,5}$ anterior open bite (AOB) isherein defined as the lack of incisal contact between anterior teeth in centric relation. Diagnosis and treatment of open bite malocclusion challenges pediatric dentists who attempt to intercept thismalocclusion at an early age. This article updates clinicians on the causes and cures of anterior open bite based on clinical data. Patients with open bite malocclusion can be diagnosed clinically and cephalometrically, however, diagnosis should be viewed in the context of the skeletal and dental structure. Accurate classification of this malocclusion requires experience and

*Corresponding author: S.JiteshBDS

Department of Prosthodontics, Saveetha Dental College and Hospital, Chennai, India training. Simple open bite during the exchange of primary to permanent dentition usually resolves without treatment. Complex open bites that extend farther into the premolar and molar regions, and those that do not resolve by the end of the mixed dentition years may require orthodontic and or surgical intervention.Vertical malocclusion develops as a result of the interaction of many different etiologic factors including thumb and finger sucking, lip and tongue habits, airway obstruction, and true skeletal growth abnormalities.Treatment for open bite ranges from observation or simple habit control to complex surgical procedures. Successful identification of the etiology improves the chances of treatment success. Vertical growth is the last dimension to be completed, therefore treatment may appear to be successful at one point and fail later. Some treatment may be prolonged, if begun early. Long-term clinical outcomes are needed to determine treatment effectiveness and clinicians should consider the cost-effectiveness of these early initiated and protracted plans. ${ }^{6}$ According to Dawson, ${ }^{7}$ the major causes of an anterior open bite are forces that result from thumb orfinger sucking, pacifier use; lip and tongue habits; airway obstruction; inadequate nasal airway creating the need for an oral airway; allergies; septum problems and blockage from turbinates; enlarged tonsils and adenoids; and skeletal growth 
abnormalities. This review will demonstrate that one factor is unlikely to be thecausative agent and a multifactoral etiology that most likely explains open bite problems. Our discussion canonlybe used as information on how to treat the condition when, and if, certain diagnostic and etiologic criteriaare present.

\section{METHODOLOGY}

A dental hospital was randomly selected in Chennai, India. A total of 100 respondents took part in the survey including the dental house surgeons, post graduate trainee of the respective colleges and students from the third and final year BDS. Participation of the respondents was voluntary. The study was conducted from $1^{\text {st }}$ December 2017 to 20th January 2017. A self-administered, close ended questionnaire was given to the voluntary respondents and the information about their knowledge, practices and attitude was evaluated (Table 1). therapy and $42 \%$ using surgical therapy. The practitioners were asked about the clinical characteristics like $17 \%$ of excess anterior face height and $18 \%$ of lip incompetence and $20 \%$ of open anterior bite. They tend to exhibit $17 \%$ of class II malocclusion and mandibular deficiency, $18 \%$ tend to exhibit crowding in the lower arch and $10 \%$ tend to exhibit a narrow maxilla and posterior cross bite. The dental practitioners were aware of the cephalometric characteristics like $22 \%$ steep palatal plane and increased percentage lower facial height, $28 \%$ excess eruption of the maxillary posterior teeth and $27 \%$ excess eruption of maxillary and mandibular incisors and the rotation of the mandible both downward and backward is $23 \%$. $70 \%$ of dental practitioners prefer the surgical therapy as the effective one out of the three therapies.

Table 1 Sample Questionnaire

\begin{tabular}{|c|c|}
\hline Questions & Options \\
\hline 1. Are you aware of anterior open bite? & $\begin{array}{l}\text { Yes }-97 \% \\
\text { No }-3 \%\end{array}$ \\
\hline $\begin{array}{l}\text { 2. Do you experience difficulties in patients with open } \\
\text { bite? }\end{array}$ & $\begin{array}{l}\text { Yes }-95 \% \\
\text { No }-5 \%\end{array}$ \\
\hline $\begin{array}{l}\text { 3. Do you have enough knowledge about management of } \\
\text { anterior open bite }\end{array}$ & $\begin{array}{l}\text { Yes }-87 \% \\
\text { No }-13 \%\end{array}$ \\
\hline 4. Treatment technique you prefer & $\begin{array}{c}\text { habit therapy } 13 \% \\
\text { appliance therapy } 45 \% \\
\text { surgical therapy } 42 \%\end{array}$ \\
\hline 5. Choose the clinical characteristics you are aware of & $\begin{array}{l}\text { Excess anterior face height, particularly in the lower third } \quad 17 \% \\
\text { Lip incompetence(resting lip separation }>4 \mathrm{~mm} \text { ) } 18 \% \\
\text { Anterior open bite (but not always, some incisors supraerupt) } \\
\text { Tend to exhibit class II malocclusion and mandibular deficiency } 17 \% \\
\text { Tend to exhibit crowding in the lower arch } 18 \% \\
\text { Tend to exhibit a narrow maxilla and posterior cross bite } \\
\text { Te\% }\end{array}$ \\
\hline & Steep palatal plane and increased percentage lower facial height \\
\hline $\begin{array}{l}\text { 6. Choose the cephalometric characteristics you are } \\
\text { aware of }\end{array}$ & $\begin{array}{c}22 \% \\
\text { Excess eruption of the maxillary posterior teeth } 28 \% \\
\text { Downward and backward rotation of the mandible } 23 \% \\
\text { Excess eruption of maxillary and mandibular incisors } 27 \%\end{array}$ \\
\hline 7. Which treatment is effective & $\begin{array}{c}\text { Habit therapy } 12 \\
\text { Appliance therapy } 18 \\
\text { Surgical therapy } 70 \\
\text { Dysphonia } 23 \% \\
\text { Tmj disorders } 32 \%\end{array}$ \\
\hline $\begin{array}{l}\text { 8. What kind of problems can open } \\
\text { bite cause }\end{array}$ & $\begin{array}{c}\text { Functional imbalance } 7 \% \\
\text { Bad aesthic } 8 \% \\
\text { Alterations of incisor guidance } 22 \%\end{array}$ \\
\hline 9. Major cause for open bite & $\begin{array}{l}\text { Reduction of normal functional activity } 8 \% \\
\text { Finger sucking,or pacifier use; } 76 \\
\text { Lip and tongue habits; } 7 \\
\text { Airway obstruction; } 4 \\
\text { Allergies; } 1 \\
\text { Septum problems andblockage from turbinates; } 3 \\
\text { Enlarged tonsils and adenoids; } 2 \\
\text { Skeletal growth abnormalities } 7\end{array}$ \\
\hline
\end{tabular}

The questionnaire was about the knowledge, awareness and management of open bite among dental practitioners and questions related to it.The values were entered and evaluated using SPSS software and the results were analyzed and represented graphically.

\section{RESULT}

In the present study, 100 dental practitioners participated in it.About $97 \%$ of the Dental practitioners were aware of anterior open bite and now $87 \%$ of them have knowledge of how to manage the anterior open bite. Around $95 \%$ of the dental practitioners find difficulty with open bite subjects. We prefer to have $13 \%$ of habit therapy, $45 \%$ in appliance
Treatment technique you prefer

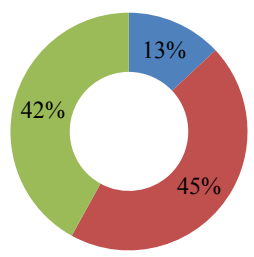

- habit therapy

- appliance therapy

n surgical therapy

Figure 1 Which Treatment technique you prefer 
Open bite causes dysphonia, tmj disorders, functional imbalance, bad aesthic, alterations of incisor guidance and reduction of normal functional activity. Major cause of open bites are Finger sucking, lip and tongue habits, allergies, airway obstruction, septum problems and blockage from turbinates, enlarged tonsils and adenoids and skeletal growth abnormalities (Figure 1-9).

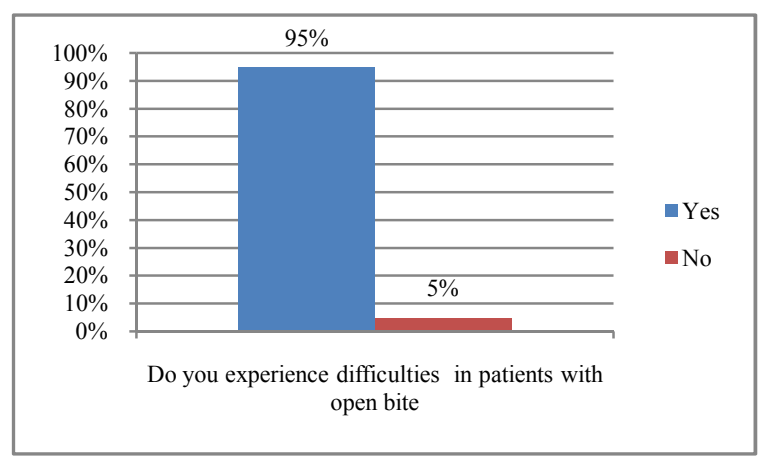

Figure 2 Difficulty In Experience In Patinets With Open Bite

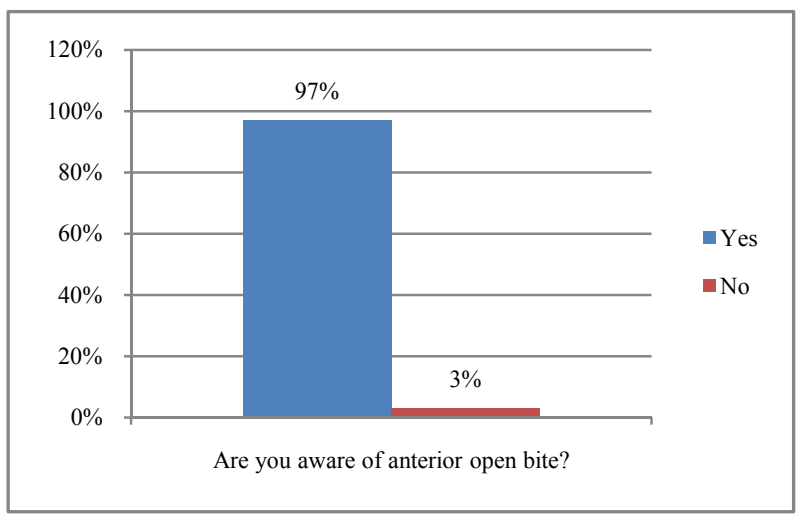

Figure 3 Awarness Of Anteriro Open Bite

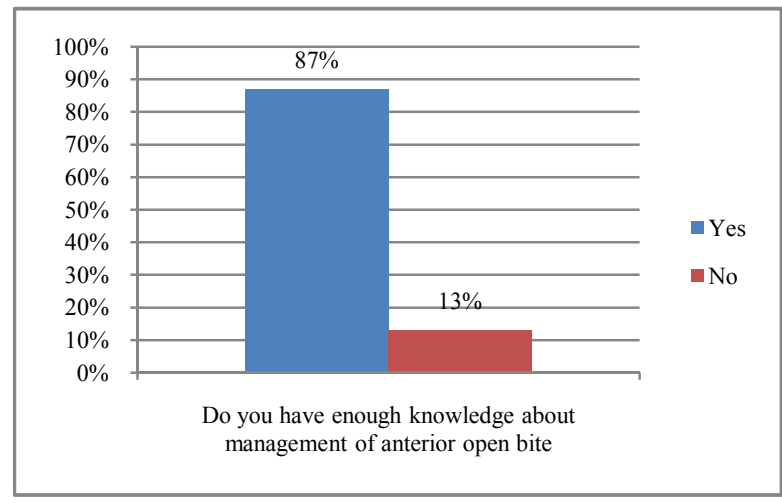

Figure 4 Knowledge on Management of Anterior open Bite

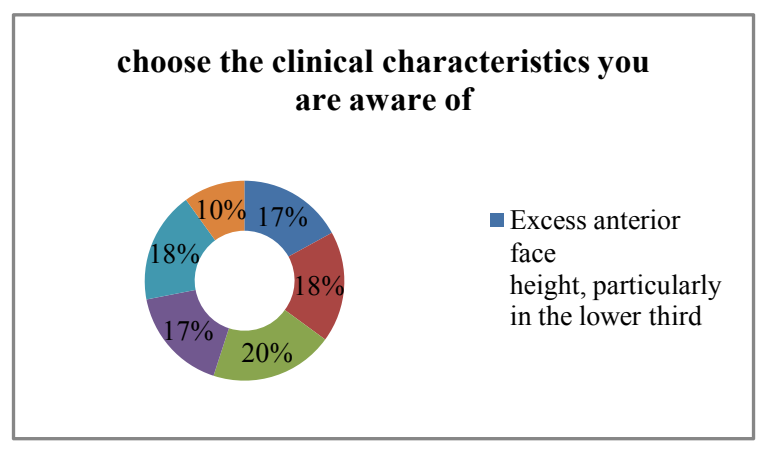

Figure 5 Awarness On Various Clinical Characteristics

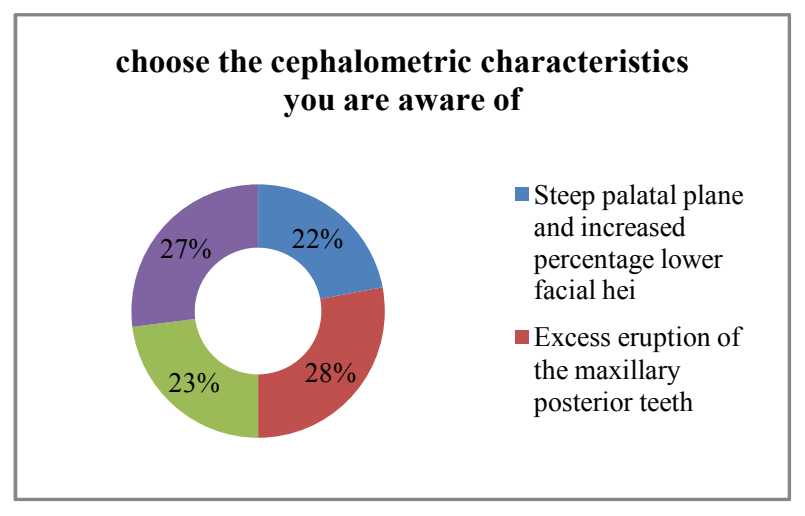

Figure 6 Awarness On Cephalometric Characteristics

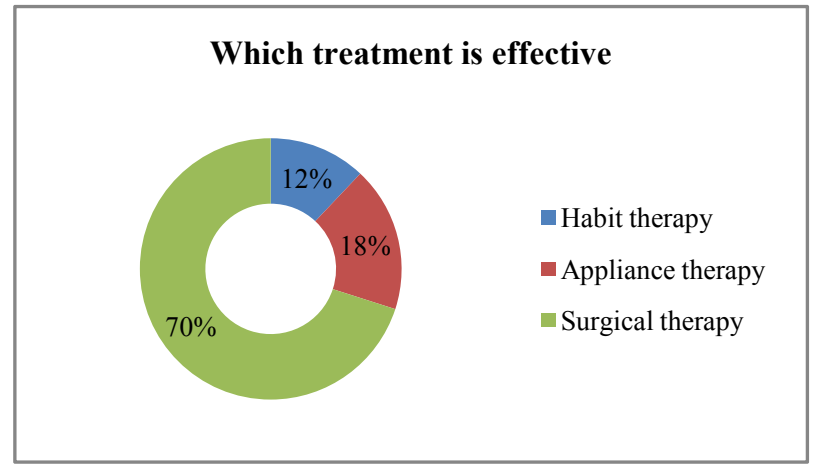

Figure 7 Effectiveness Of Various Treatment

What kind of problems can open bite cause

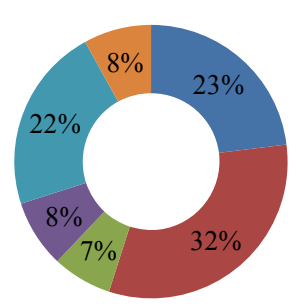

- Dysphonia

- Tmj disorders

Functional

imbalance

- Bad aesthic

Figure 8 Various Problems Of Anterior Open Bite

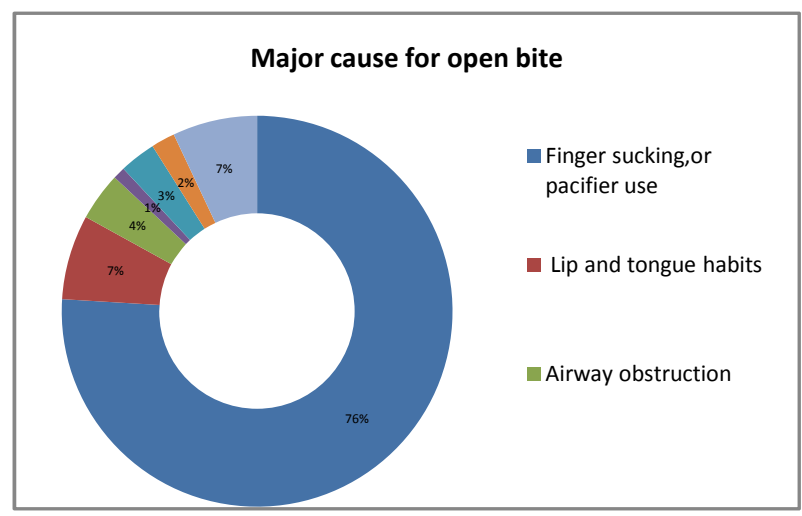

Figure 9 Various Causes Of Anterior Open Bite

\section{DISCUSSION}

Anterior open bite is considered to be one of the most difficult treatments. Proper diagnosis and treatment planning, successful treatment, and retention have been stressed for the 
long-term stability of open bite treatment. There are several factors that could be related to the development of open bite. Among these are an unfavorable mandibular growth pattern, heredity, imbalances between jaw postures, digit-sucking habits, nasopharyngeal airway obstruction, tongue posture and activity and head position. ${ }^{8}$ The present study examined the knowledge, awareness and management of anterior open bite among dental practitioner and were found that dental practitioner were aware about of anterior open bite but were lacking knowledge about the management of anterior open and various clinical characterstics. From the above findings we get to know that about $97 \%$ of the Dental practitioners are aware of anterior open bite and now $87 \%$ of them have knowledge of how to manage the anterior open bite.And about $95 \%$ were facing dificulties in patients with open bite. Dental practitioner prefer appliance therapy over surgical therapy and habit therapy even though surgical treatment was effective.Various treatment modalities have been proposed for the correction of anterior open bites. Nonsurgical therapies that have been used for treatment and/or retention of anterior open bite cases include multiloop edgewise archwires, ${ }^{10}$ tongue crib therapy, ${ }^{11}$ posterior bite blocks with $^{12}$ and without magnets, ${ }^{13}$ and functional appliances. ${ }^{14}$ In general, stability is the most important criteria in choosing an acceptable method of treatment for patients with open bite malocclusion. Many previous studies ${ }^{15,16}$ have indicated that if open bite correction is not stable, it is because the tongue continues to be postured anteriorly which causes the bite to reopen. ${ }^{9}$ Open bite causes dysphonia, tmj disorders, functional imbalance, bad aesthic ,alterations of incisor guidance and reduction of normal functional activity. Major cause of open bites are Finger sucking, lip and tongue habits, allergies, airway obstruction, septum problems and blockage from turbinates, enlarged tonsils and adenoids and skeletal growth abnormalities.

\section{CONCLUSION}

The present study reveals that even though the dental practioners were aware of anterior open bite they should also have adequate knowledge about the management of anterior open bites. Further awareness would enhance the efficacy of usage and overcome the difficulties faced while practicing. This study concludes that it must be necessary to increase the awareness among dental practitioner about the management and the treatment measures of anterior open bite

\section{Reference}

1. Parker JH. The interception of the open bite in the earlygrowthperiod.AngleOrthod. 1971 Jan;41(1):24-44.

2. Subtelny HD, Sakuda M. Open bite: diagnosis andtreatment. Am J Orthod. 1964 May;50(5):337-58.

3. Huang GJ, Justus R, Kennedy DB, Kokich VG. Stability ofanterioropenbite treated with crib therapy. Angle Orthod.1990 Jun;10(1):17-24.

4. Shapiro PA. Stability of open bite treatment. Am J OrthodDentofacialOrthop. 2002 June;121(6):566-8.

5. Cozza P, Mucedero M, Baccetti T, Franchi L. Earlyorthodontic treatment of skeletal open bite malocclusion: asystematic review. Angle Orthod. 2005 Sept;75(5):707-13.

6. Pediatr Dent 19:91-98, 1997)

7. Dawson PE: Evaluation, Diagnosis, and Treatment of Occlusal Problems, 2nd ed. St Louis, MO:C VM osbyC o, 1989, pp 535-42.

8. Nielsen, I.L.: Vertical malocclusions: etiology, development, diagnosis and some aspects of treatment, Angle Orthod. 61:247-260, 1991.

9. Open bite: a review of etiology and management Peter Ngan, DMD Henry W. Fields, DDS, MS, MSD

10. Kim, Y.H.; Han, U.K.; Lim, D.D.; and Serraon, L.P.: Stability of anterior openbite correction with multiloop edgewise archwire therapy: A cephalometric follow-up study. Am. J. Orthod. 130: 391-402, 2006.

11. Huang, G.J.; Justus, R.; Kennedy, D.B.; and Kokich, V.G.: Stability of anterior openbite treatment with crib therapy. Angle Orthod. 60:17-24, 1990.

12. Woods, M.G. and Nanda, R.S.: Intrusion of posterior teeth with magnets. Angle Orthod. 58:136-150, 1988.

13. Woodside, D. and Aronsen, S.: Progressive increases in lower anterior face height and the use of posterior biteblock in its management: treatment and technique principles. in Orthodontics, state of the art: essence of the science, ed. L.W. Graber, Mosby, St Louis, 1986, pp. 200-221.

14. Frankel, R. and Frankel, C: A functional approach to treatment of skeletal openbite. Am. J. Orthod. 83:5468, 1983.

15. Shapiro, P.A.: Stability of open bite treatment. Am. J. Orthod.121:566-568, 2002.

16. Huang, G.J.: Long-Term Stability of Anterior Openbite Therapy: A Review. Semin.Orthod. 8:162-72, 2002.

\section{How to cite this article:}

S.JiteshBDS et al (2017) ' Knowledge and Awareness Among Dental Practitioner Regarding The Management of Anterior Open Bite', International Journal of Current Advanced Research, 06(04), pp. 3094-3097.

DOI: http://dx.doi.org/10.24327/ijcar.2017.3097.0191 